\title{
HUBUNGAN MOTIVASI BELAJAR DENGAN HASIL BELAJAR MASASE DASAR MAHASISWA FIK UNP.
}

\author{
Darni $^{1}$, Edwarsyah $^{2}$, Eldawaty $^{3}$ \\ ${ }^{1}$ Program Studi Pendidikan Jasmani Kesehatan dan Rekreasi, Fakultas Ilmu Keolahragaan, \\ Universitas Negeri Padang, Jalan Prof. DR. Hamka Air Tawar Barat, Padang, 25132, Indonesia \\ ${ }^{2}$ Program Studi Pendidikan Jasmani Kesehatan dan Rekreasi, Fakultas Ilmu Keolahragaan, \\ Universitas Negeri Padang, Jalan Prof. DR. Hamka Air Tawar Barat, Padang, 25132, Indonesia
}

E-Mail: darni@fik.unp.ac.id ${ }^{1}, \underline{\text { edwarsyah@fik.unp.ac.id }}{ }^{2}$, eldawaty@ fik.unp.ac.id $^{3}$

\begin{abstract}
ABSTRAK
Masalah dalam penelitian ini adalah hasil belajar masase dasar mahasiswa FIK UNP hanya 2,6 persen mahasiswa yang memperoleh nilai A- dan tidak ada mahasiswa yang mampu mencapai nilai A dengan rentang nilai 85-100, serta banyaknya mahasiswa yang memperoleh nilai E. Sesuai dengan hal tersebut, maka penelitian ini bertujuan untuk mengungkap hubungan motivasi belajar dengan hasil belajar masase dasar mahasiswa FIK UNP.

Jenis penelitian ini adalah korelasional sederhana yang ingin melihat hubungan motivasi belajar dengan hasil belajar masase dasar mahasiswa FIK UNP. Motivasi belajar sebagai variabel bebas dan hasil belajar sebagai variabel terikat. Populasi pada penelitian ini adalah Mahasiswa FIK UNP yang terdaftar pada semester Januari - Juni tahun pelajaran 2014 yang berjumlah 640 orang. Penarikan sampel dilakukan dengan teknik purposive sampling, sehingga sampel adalah mahasiswa Pendidikan Olahraga yang berjumlah 66 orang. Instrumen yang digunakan untuk mengukur motivasi belajar adalah angket menggunakan skala likert dan hasil belajar menggunakan nilai semester mahasiswa semester Januari - Juni 2014. Data dianalisis dengan menggunakan rumus korelasi sederhana Product Moment.

Hasil penelitian menunjukkan motivasi belajar memiliki hubungan signifikan dengan hasil belajar masase dasar, diperoleh $r_{\text {hitung }}=0,533>r_{\text {tabel }}=0,235$ pada taraf $\alpha=0,05$ demikian juga uji signifikan menunjukkan $\mathrm{t}_{\text {hitung }} 6,98>\mathrm{t}_{\text {tabel }} 1,663$, dengan demikian hipotesisi kerja yang diajukan diterima. jadi terdapat hubungan yang signifikan antara motivasi belajar dengan hasil belajar masase dasar mahasiswa FIK UNP.
\end{abstract}

Kata Kunci: Motivasi Belajar, Hasil Belajar, Masase

\section{PENDAHULUAN}

Fakultas Ilmu Keolahragaan Universitas Negeri Padang (FIK UNP) mempunyai visi dan misi diantaranya: 1) Visi : Visi Fakultas Ilmu Keolahragaan yang memiliki budaya akademik yang unggul, dinamis bermutu tinggi, dalam bidang keolahragaan yang semangat untuk menjadi yang terbaik dalam menghasilkan tenaga kependidikan, kepelatihan dan ilmuan keolahragaan yang profesional serta berdaya saing pada tahun 2015, beriman dan bertakwa pada Tuhan Yang Maha Esa.

2) Misi : (1) melaksanakan Tri Darma Perguruan Tinggi dalam bidang ilmu keolahragaan yang handal dan Produktif serta berdaya saing global, (2) melakukan pengkajian ilmu keolahragaan berdasarkan kepada prinsip keilmuan, etika dan moral, (3) memperluas hasil kajian ilmu keolahragaan untuk dapat dimanfaatkan bagi kemaslahatan masyarakat, bangsa dan Negara, (4) menjunjung tinggi intelektualitas dan mengutamakan pelayanan profesional dalam bidang keolahragaan sebagai pengabdian terhadap kepentingan pembangunan daerah dan nasional serta internasional.

Untuk mencapai misi dan visi tersebut diselengggarakanlah kurikulum perkuliahan, di dalam kurikulum perkuliahan terdapat mata kuliah wajib, mata kuliah pilihan, mata kuliah umum, mata kuliah keahlian bekarya, mata kuliah prilaku berkarya, dan mata kuliah berkehidupan bermasyarakat.Salah satu mata kuliah wajib mahasisiwa Fakultas Ilmu Keolahragaan Universitas Negeri Padang adalah masase dasar.

Mahasiswa harus menguasai pembelajaran masase dasar, bukan hanya untuk memperoleh nilai, tapi berguna nantinya

Hubungan Motivasi Belajar Dengan Hasil..... 10 Edwarsyah ${ }^{1}$, Hilmainur Syampurma ${ }^{2}$ 
setelah menyelasaikan studi di FIK UNP baik sebagai guru olahraga, pelatih olahraga dan ilmuan olahraga.Agar mahasiswa FIK UNP mampu menguasai pembelajaran masase dasar dibangku perkuliahan, dosen pengajar memberikan metode-metode pengajaran, seperti memperkenalkan pentingnya masase dasar bagi mahasiswa Fakultas Ilmu Keolahragaan, adanya pemahaman materi masase dasar (buku panduan), memberikan praktek masase di saat perkuliahan, bahkan bagi mahasiswa yang berminat mendalami masase, dosen bersangkutan membuka pelatihan masase di luar jam pelajaran.

Begitu besarnya perhatian dosen masase untuk menunjang agar mahasiswa memiliki keterampilan masase, namun dari observasi penulis sewaktu mengikuti perkuliahan masase dasar, banyak mahasiswa yang kurang keseriusannya dalam mengikuti perkuliahan, diantaranya banyaknya mahasiswa yang sering terlambat masuk perkuliahan masase, tidak ada latihan di luar jam perkuliahan padahal , hal ini sudah ditugaskan kepada mahasiswa agar mempraktekkan masase di luar jam perkuliahan dengan pasiennya adalah Dosen FIK UNP dengan mengisi blangko pasien yang telah diberikan oleh dosen masase. Sejalan dengan penyataan diatas, demikian juga dengan Dosen yang bersangkutan, masih rendahnya hasil belajar mahasiswa Fakultas Ilmu Keolahragaan.

Dari pendapat diatas dapat diambil kesimpulan, bahwa belajar itu adalah proses pembaharuan yang alami oleh individu yang diperolehnya secara langsung bukan bawaan sejak lahir atau warisan keturunan namun berdasarkan latihan dan pengalaman yang memungkinkan mereka menjadi terampil. Dan belajar menyebabkan adanya perubahan baik tingkah laku maupun pengetahuan, perubahanperubahan itu terjadi karena adanya usaha yang dilakukan atau usaha yang disengaja dan belajar itu mempunyai tujuan-tujuan tertentu.

Untuk dapat mencapai tujuan itu, maka setiap mahasiswa harus mengetahui prinsipprinsip belajar tersebut.Slameto (2010:27) mengemukakan prinsip-prinsip belajar, yaitu : 1) Belajar harus dapat menimbulkan reinforcement dan motivasi yang kuat pada peserta didik untuk mencapai tujuan, 2) Belajar itu proses kontinue, maka harus tahap demi tahap menurut perkembangannya, 3)Belajar harus dapat mengembangkan kemampuan tertentu sesuai dengan tujuan yang harus dicapainya, 4)Belajar memerlukan latihan dan ulangan agar apa yang dipelajari dapat dikuasai, 5)Belajar harus disertai keinginan dan kemampuan yang kuat untuk mencapai tujuan, 6)Belajar dianggap berhasil apabila telah sanggup menerapkan kedalam bidang praktek sehari-hari.

Di dalam setiap proses pembelajaran ada tiga aspek yang selalu mendasari menurut Syaiful Sagala (2012:12) mengatakan : Untuk menangkap isi dan pesan belajar, maka dalam proses tersebut individu menggunakan kemampuan pada ranah : 1) kognitif yaitu kemampuan yang berkenaan dengan pengetahuan, penalaran atau pemikiran terdiri dari kategori pengetahuan, pemahaman, penerapan, analisis, sintesis dan evaluasi: 2) afektif yaitu kemampuan yang mengutamakan perasaan emosi, dan reaksi-reaksi yang berbeda dengan penalaran yang terdiri dari kategori peneriman, partisispasi, penilaian/penentuan sikap, organisasi, dan pembentukan pola hidup: 3) psokomotorik yaitu kemampuan yang mengutamakan keterampilan jasmani yang terdiri dari persepsi, kesiapan , gerak terbimbing, gerakan terbiasa, gerakan kompleks, penyesuaian pola gerakan, dan kreatifitas.

Dalam proses belajar adanya tingkat pengukuran kemampuan dengan bentuk penilaian dan tujuan akhir yang ingin dicapai dari sebuah proses pembelajaran adalah untuk melihat hasil yang didapat dari proses pembelajaran itu sendiri. Menurut Sukmadinata (2011:173) "hasil belajar merupakan realisasi atau pemekaran dari kecakapan-kecakapan potensial atau kapasitas yang dimiliki seseorang. Dan ditambah hasil belajar bukannya berupa penguasaan pengetahuan tetapi juga kecakapan, keterampilan".

Dari pengertian hasil belajar diatas, menunjukkan adanya persamaan yang cukup mendasar yaitu perubahan tingkah laku yang relatif permanen sebagai hasil belajar atau latihan. Semakin sering latihan yang dilakukan seseorang yang sedang belajar, maka perubahan yang dialami akan lebih permanen dan menetap. Tetapi dalam belajar perlu diperhatikan bagaimana prosesnya berlangsung, karena bagaimana pun proses memegang peranan penting dalam mencapai tujuan belajar.

Hubungan Motivasi Belajar Dengan Hasil..... 11 Edwarsyah $^{1}$, Hilmainur Syampurma ${ }^{2}$ 


\section{Motivasi Belajar}

Setiap individu memiliki kondisi internal dan kondisi eksternal, dimana kondisi internal dan eksternal tersebut turut berperan dalam aktifitas dirinya sehari-hari. Salah satu dari kondisi internal dan eksternal tersebut adalah motivasi instrinsik dan motivasi ekstrinsik

Secara garis besar motivasi merupakan dorongan dasar yang menggerakkan seseorang bertingkah laku, dorongan ini berada pada diri seseorang yang menggerakkan untuk melakukan sesuatu yang sesuai dengan dorongan dalam dirinya. Oleh karena itu, perbuatan seseorang yang didasarkan atas motivasi tertentu mengandung tema sesuai dengan motivasi yang mendasarinya.

Dalam pengertiannya "Motivasi adalah dorongan atau kehendak yang menimbulkan atau menyebabkan timbulnya semacam kekuatan sehingga seseorang berbuat atau bertindak dengan kata lain bertingkah laku dengan tingkah laku di latar belakangi oleh suatu motif, maka diikenal dengan tingkah laku bermotivasi" (Syahrastani, 1999:11).

Secara umum motivasi dapat diartikan sebagai daya yang menggerakkan aktivitas seseorang. Dengan demikian motivasi merupakan pendorong untuk melakukan sesuatu, baik dalam proses belajar mengajar maupun dalam kegiatan lain. Munculnya keinginan untuk beraktifitas menunjukkan adanya motif pendorong pelaku aktifitas tersebut.

Dalam motivasi terkandung keinginan yang mengaktifkannya, menggerakkannya, mengarahkan sikap dan perilaku individu belajar. Sejalan dengan hal tersebut bahwa motivasi mampu menggerakkan seseorang untuk mencapai tujuan yang ingin dicapai sehingga bagi mahasiswa motivasi belajar merupakan hal yang sangat penting, dapat dijabarkan pentingnya motivasi belajar adalah sebagai berikut: Pertama, Menyadarkan kedudukan pada awal belajar, proses dan hasil akhir; contoh, setelah seseorang membaca suatu bab buku bacaan, dibandingkan dengan temannya, ia kurang berhasil menangkap isi, maka ia terdorong membaca lagi.

Kedua, Menginformasikan tentang kekuatan belajar; contoh, yang dibandingkan dengan teman sebagai ilustrasi, jika terbukti usaha yang dilakukan mahasiswa belum memadai, maka ia berusaha setekun temannya.
Ketiga, Mengarahkan kegiatan belajar; contoh, setelah ia ketahui bahwa dirinya belum belajar secara serius, terbukti banya bersenda gurau misalnya, maka ia akan mengubah perilaku belajarnya.

Keempat Membesarkan semangat belajar; contoh, dengan instropeksi diri, mengingat dengan telah banyaknya mengahabiskan biaya kuliah yang cukup besar, padahal masih ada adik yang masih di biayai orang tua, maka ia berusaha akan cepat lulus.

Ada dua jenis motivasi yaitu motivasi instrinsik dan motivasi ekstrinsik, motivasi instrinsik yaitu dorongan dari dalam diri untuk berbuat demi tujuan yang ingin dicapai, sedangkan motivasi ekstrinsik yaitu dorongan yang datang dari luar diri pribadi untuk berbuat demi tujuan".

a. Motivasi Instrinsik

Motivasi instrinsik menurut Syaiful Bahri (2011:148) yaitu "motif-motif yang menjadi aktif atau berfungsinya tidak perlu dirangsang dari luar, karena dalam setiap diri individu sudah ada dorongan untuk melakukan sesuatu tanpa ada pengaruh dari luar individu yang digerakkan oleh motivasi instrinsik baru akan puas kalau kegiatan yang dilakukan dalam hal ini perkuliahan masase dasar telah mencapai hasil yang diinginkan".

Mahasiswa yang memiliki motivasi instrinsik akan mengikuti perkuliahan dan belajar dengan bersungguh-sungguh untuk memperoleh hasil belajar yang baik bukan disebabkan oleh situasi buatan seperti dorongan dari luar misalnya, orang tua, pacar, teman, hadiah yang dijanjikan.Indikatorindikator yang termasuk dalam motivasi belajar yang berasal dari faktor psikis atau dalam diri.

Menurut pendapat Anderson dan Faust dalam Prayitno (1989:10) mengemukakan indikator motivasi belajar adalah : "minat, ketajaman perhatian, konsentrasi, dan ketekunan". Sedangkan Winkel (1984:8) mengemukakan indikator motivasi belajar adalah; "sikap, perasaan, minat, bakat.

Dalam pembahasan selanjutnya dijelaskan indikator-indikator yang diuraikan diatas.

1) Minat

Menurut kamus umum bahasa Indonesia mengemukakan pengertian minat adalah keinginan, perhatian, kesukaan atau 
kecendrungan hati kepada sesuatu, seseorang yang berminat terhadap suatu objek tidak dapat dihalangi oleh orang lain dan dia akan berusaha untuk mendapatkannya.

Dari beberapa pendapat yang telah dikemukan di atas dapat disimpulkan bahwa minat merupakan kecendrungan hati yang tinggi dari seseorang yang mendorongnya untuk bertindak, menyenangi, mempersoalkan, berbuat, menanggapi, atau menerima suatu objek dan aktifitas dan melibatkan dirinya sungguh-sungguh bermanfaat untuk pertumbuhan dan perkembangan fisik serta minat merupakan suatu energi penggerak dari dalam hati pada diri seseorang yang menyebabkannya menaruh perhatian serius terhadap sesuatu kegiatan tertentu tanpa ada unsur paksaan dari luar dirinya, sehingga sulit untuk berpaling dari kegiatan yang ditekuninya. Dalam hal ini seorang mahasiswa akan mengikuti perkuliahan masase dasar dengan sepenuh hati jika keinginan yang tinggi muncul dari dalam diri mahasiswa tersebut.

Seorang mahasiswa yang mengikuti perkuliahan masase dasar sudah timbul dalam dirinya keinginan di karenakan mahasiswa tersebut mengetahui betapa pentingnya pembelajaran masase bagi seorang olahragawan, calon guru dan calon pelatih dalam dunia olahraga, maka mahasiswa tersebut akan bersungguh-sungguh dalam mempelajarinya.

Minat seseorang dapat dilihat dari objek yang dipilihnya, dan kegiatan yang dipilih tersebut akan kelihatan melalui cara-cara seseorang bertindak, memperhatikan dan melakukan kegiatan yang berhubungan dengan objek tersebut.

Suryabrata dalam Almen (2006:9) mengatakan, "bila seseorang berminat terhadap suatu objek, maka orang tersebut akan memusatkan tenaga psikisnya yang tertuju pada suatu objek". Pendapat ini mengemukakan apabila seseorang berminat terhadap suatu objek maka orang akan memfokuskan diri pada objek tersebut.

Dari pendapat ini seorang mahasisiwa yang berminat terhadap suatu kegiatan tidak akan dapat dihalangi oleh orang lain, dan ia berusaha untuk mendapatkannya, sebab menurutnya objek tersebut telah bersatu dengan dirinya, disini perkuliahan masase telah menjadi perhatian khusus karena mahasiswa tersebut telah menngetahui manfaat dan tujuan dari mempelajari masase dasar ini dibangku perkuliahan.

Para mahasiswa yang tidak berminat cenderung akan menghambat pembentukan kebiasaan dirinya untuk belajar secara baik, sehingga mengakibatkan sikap malas dan menyebabkan hasil belajarnya menurun.

Pembahasan minat yang diuraikan diatas bila dikaitkan dengan perkuliahan masase dasar di kalangan mahasiswa akan jelas bagi kita, bahwa mahasiswa yang memiliki minat yang tinggi akan merasa tertarik dan senang untuk mengikuti perkuliahan.

Agar seseorang dapat menentukan dan memilih jenis kegiatan dan pekerjaan yang sesuai dengan minatnya perlu adanya persiapan, persiapan tersebut diawali dengan jalan membayangkan, memikirkan, mengharapkan dan mencita-citakan manfaat dalam mempelajari perkuliahan masase dasar.

Dalam pembelajaran masase sikap seorang mahasiswa sangat berpengaruh, untuk menentukan suka atau tidak sukanya mengikuti perkuliahan masase.Mahasiswa yang bersikap menerima, mengamati, dan mengikuti perintah doosen berarti mereka menyenangi perkuliahan masase, sebaliknya mahasiswa yang bertingkah aneh seperti meribut, mengganggu teman, dan tidak mengikuti perintah dosen, berarti mahasiswa tsb tidak menyukai perkuliahan masase.

Memperkuat pernyataaan diatas maka Hamzah (2012:190) mengungkapkan ciri-ciri sikap sebagai berikut:

(1) Dalam sikap selalu terdapat hubungan subyek-obyek, (2) Sikap tidak dibawa sejak lahir, melainkan dipelajari dan dibentuk melalui pengalaman-pengalaman, (3) Sikap dapat berubah-ubah sesuai dengan keadaan lingkungan disekitar individu pada saat-saat yang bebeda, (4) Dalam sikap tersangkut juga sikap motivasi dan perasaan, (5) Sikap tidak menghilang walaupun kebutuhan sudah dipenuh.

Sikap selalu memiliki peranan penting bagi seorang individu, apakah antara orang tua dan anak maupun antara pendidik dan peserta didiknya. Hal ini saling memiliki keterkaitan, sikap mahasiswa terhadap dosen sangat menentukan proses perkuliahan dapat berjalan efektif, mahasswa yang bersikap sesuai 
dengan arahan dosen maka perkuliahan akan berjalan dengan baik, dan sebaliknya.

Sikap pada dasarnya bukan bawaan sejak lahir namun tumbuh berdasarkan pengalaman-pengalaman yang dilalui oleh seorang individu, sikap pun dapat berubahrubah sesuai dengan keadaan lingkungan, begitu halnya dengan pembelajaran masase, dengan keadaan dosen sebagai tenaga pendidik, menuntut mahasiswa untuk bisa menguasai keterampilan masase sejalan dengan keinginan peserta didik untuk mahir dibidang masase, maka secara langsung membentuk sikap yang sejalan dengan tujuannya.

Sikap sangat erat hubungannya dengan motivasi dan perasaan, dapat kita jelaskan seseorang yang memiliki perasaan yang peka serta adanya motivasi dalam diri apapun bentuk yang akan dilakukan maka akan berjalan dengan lancar dan bersungguhsungguh. Bagi pendidik, tinggal mengarahkan serta memberikan pemahaman materi masase tersebut.Jadi pada kesimpulannya sikap memegang peranan penting bagi mahasiswa dalam mempelajari pembelajaran masase di FIK UNP.

Berdasarkan kutipan di atas, jelas betapa pentingnya penguasaan metode beberapa atau keseluruhan dosen. Seseorang dosen yang sangat miskin akan metode pencapaian tujuan, yang tidak menguasai berbagai teknik mengajar atau mungkin tidak mengetahui adanya metode-metode itu, akan berusaha mencapai tujuannya dengan jalan yang tidak wajar.

Hasil pengajaran yang serupa ini selalu menyedihkan. Sebaliknya mengajar dengan mempergunakan metode yang beraneka ragam dan disertai oleh pengertian yang dalam dari pihak dosen, akan memperbesar minat belajar mahasiswa dan akibatnya akan mempertinggi pula hasil yang diharapkan.

Dengan mengajak, merangsang dan memberikan kesempatan pada mahasiswa untuk ikut serta mengemukakan pendapat, belajar mengambil keputusan, bekerja dalam kelompok, membuat laporan, berdiskusi dan lain-lainnya lagi, berarti membawa mereka kedalam suasana belajar atau kuliah yang sesungguhnya dan bukan pada suasana diajar atau dikuliahi belaka.

Didalam hal ini, beberapa metode pengajaran, pertama penyajian pengajaran melalui konsep metode analisti adalah segala elemen gerakan dipisahkan dari gerakan keseluruhan. Dengan melatih setiap bagian, selanjutnya dosen memperbaiki kesalahankesalahan yang dilakukan mahasiswa menerapkannya sesuai petunjuk dari dosen tersebut.Sedangkan konsep metode sintetis adalah dosen menjelaskan dan mendemonstrasikan keseluruhan elemenelemen gerakan yang ada dalam memberikan perkuliahan.

Selanjutnya mahasiswa melatihkan keseluruhan gerakan tersebut secara kasar dan kemudian dosen memperbaiki kesalahnkesalahan yang dilakukan mahasiswa tersebut.Akhirnya mahasiswa menerapkan perbaikan-perbaikan gerakan sesuai dengan petunjuk dosen yang bersangkutan.

\section{METODE DAN HASIL}

Menurut A.Muriyusuf (2007:84) mengatakan"Penelitian korelasional merupakan suatu tipe penelitian yang melihat hubungan antara satu atau beberapa ubahan dengan satu atau beberapa ubahan yang lain". Jadi dapat kita simpulkan Jenis penelitian ini adalah korelasional yaitu suatu penelitian untuk menentukan tingkat hubungan antara variabel yang berbeda serta besarnya kontribusi variabel bebas terhadap variabel terikat.

Tempat penelitian ini adalah di Labor Masase FIK UNP yang dilaksanakan pada semester Januari-Juni 2014.Populasi adalah merupakan totalitas semua nilai-nilai yang mungkin dari pada karakteristik tertentu sejumlah objek yang ingin dipelajari sifatsifatnya.

Sedangkan Menurut Sugiyono (2006:117) "populasi adalah wilayah generalisasi yang terdiri atas objek/subjek yang mempunyai kuantitas dan karakteristik tertentu yang ditetapkan oleh peneliti untuk dipelajari, diteliti dan kemudian ditarik kesimpulannya". Sebagai populasi dalam penelitian ini adalah seluruh mahasiswa FIK UNP yang mengambil mata kuliah masase dasar pada semester JanuariJuni 2014 dengan jumlah keseluruhan mahasiswa 646 orang

Sampel menurut A. Muriyusuf (2007:186) adalah "sebagian dari pupolasi yang terpilih dan mewakili populasi tersebut"..Memperhatikan jumlah anggota populasi cukup besar, maka 
pengambilan sampel dalam penelitian ini dilakukan dengan teknik purposive Sampling.

Teknik porpusive sampling menurut A Muriyusuf (2007:205)diartikan sebagai maksud, tujuan atau kegunaan, penentuan sampel secara porpusive dilandasi tujuan atau pertimbanganpertimbangan tertentu terlebih dahulu.

Maka dalam penelitian ini sampel yang akan peneliti ambil adalah mahasiswa Jurusan Pendidikan Olahraga FIK UNP dikarenakan dengan banyaknya tenaga pendidik (dosen) dalam pelaksanaan perkuliahan dibandingkan dengan Jurusan Pendidikan Kepelatihan FIK UNP,

Sehingga adanya variasi dalam memberikan metode-metode pengajaran pada masing-masing mahasiswa yang mengambil mata kuliah masase dasar pada Jurusan Pendidikan Olahraga. Arikunto (1992:34) mengemukakan bahwa "Populasi yang kurang dari seratus lebih baik diambil semuanya menjadi sampel yang disebut sampel pupulasi.

Apabila populasinya lebih dari seratus, maka bisa diambil sampel $10-20 \%, 20-25$ $\%$, dan $30-35 \%$ dan seterusnya". Dalam penelitian, sampel diambil secara porposiveSampling yaitu $20 \%$ dari populasi mahasiswa Jurusan Pendidikan Olahraga dengan jumlah sampel 66 orang.

Berdasarkan permasalahan yang akan diteliti maka dalam penelitian ini terdapat dua variabel penelitian yaitu : motivasi sebagai variabel bebas $(\mathrm{x})$ dan hasil belajar masase dasar mahasiswa FIK UNP sebagai variabel terikat $(\mathrm{y})$.

Berdasarkan jenis data yang digunakan dalam penelitian ini adalah data primer dan data sekunder. Data primer yaitu data yang diambil langsung dikumpulkan oleh peneliti dari mahasiswa FIK UNP yang mengambil mata kuliah masase dasar semester JanuariJuni 2014 yaitu dengan cara menyebarkan angket pada mahasiswa tersebut.

Data sekunder yaitu data yang telah ada berupa dokumen hasil belajar masase dasar mahasiswa FIK UNP semester Januari-Juni 2014 yang bersumber dari dosen pengajar.

Sumber data dalam penelitian ini adalah mahasiswa FIK UNP yang mengambil mata kuliah masase dasar semester Januari-Juni 2014.

\section{Teknik dan Alat Pengumpulan Data}

Usaha untuk memperoleh data dalam penelitian ini yaitu ditempuh dengan prosedur penyebaran angket (kuisioner) pada mahasiswa FIK UNP yang mengambil mata kuliah masase dasar. Dengan langkah-langkah sebagai berikut.

1. Membuat angket yang disertai dengan pertanyaan

2. Uji coba angket

3. Menyebarkan angket

4. Mengumpulkan angket yang telah dijawab oleh responden

5. Pengecekan kebenaran pengisiannya

6. Melakukan pengolahan data

\section{Instrumen Penelitian}

1. Motivasi

Teknik pengumpulan data dalam penelitian ini menggunakan instrumen berupa angket atau kuisioner tertutup yaitu berupa pertanyaan, artinya responden atau mahasiswa hanya diberi kesempatan untuk memilih jawaban yang sesuai dengan motivasinya. Alternatif jawaban adalah berupa skala Likert, sekala yang terdiri dari lima angka, skala tersebut diasumsikan. Skala ini digunakan untuk tingkat yang sangat tinggi.Dapat diasumsi bahwa jawaban yang ada pada sekala merupakan ukuran yang kuantitatif.Angket yang digunakan adalah angket tertutup, yaitu jawabannya sudah disediakan oleh responden, hanya tinggal memilih satu alternative jawaban saja. Ada lima alternative tersebut, sebagai berikut:

Tabel. 6 Alternatif Jawaban Kuisioner (angket)

\begin{tabular}{|l|c|c|c|}
\hline \multicolumn{1}{|c|}{ Jawaban } & Simbol & $(+)$ & $(-)$ \\
\hline Sangat Setuju & SS & 5 & 1 \\
\hline Setuju & S & 4 & 2 \\
\hline Ragu-ragu & RG & 3 & 3 \\
\hline Tidak Setuju & TS & 2 & 4 \\
\hline Sangat Tidak Setuju & STS & 1 & 5 \\
\hline
\end{tabular}

Sumber : A. Muri Yusuf (2007:303)

\section{Hasil belajar}

Dalam penelitian ini, peneliti mengaitkan variabel (y) hasil belajar mahasiswa dari nilai semester yang diperoleh dari dosen yang mengajar mata kuliah masase dasar mahasiswa FIK UNP semester JanuariJuni 2014

Teknik Analisis Data

Mengenai teknik analisis data yang digunakan dikutip dari Nasution (1998:16) adalah teknik analisis data dalam penelitian tergantung pada jenis data penelitian. 
Setelah mendapatkan hasil dari korelasi product moment, kemudian dilanjutkan pengujian hipotesisdengan Uji distribusi t yang bertujuan menguji apakah terdapat hubungan motivasi belajar (X) dengan hasil belajar(Y). Pengujian ini dilakukan dengan cara membandingkan nilai $t_{\text {hitung }}$ dengan $t_{\text {tabel }}$ pada statistik distribusi t.

\section{HASIL DAN PEMBAHASAN}

Dari sampel yang diteliti sebanyak 66 orangPengolahan data penelitian motivasi belajar sebagai variabel $(\mathrm{X})$ diperoleh mean $=$ 104,74 , standar deeviasi $=8,16$, nilai minimum $=87$ dan nilai maksimum $=121$, sedangkan hasil belajar sebagai variabel (Y) diperoleh mean $=79,23$, standar deviasi $=$ 4,62 , nilai minimum $=70$ dan nilai maksimum $=90$ untuk lebih jelasnya dapat dilihat tabel dibawah ini:

Tabel 7. Rerata hitung dan Standar Deviasi Data Penelitian

\begin{tabular}{|c|c|c|c|c|c|}
\hline Variabel & $\mathbf{N}$ & Rata-rata & Std.dev & MIN & MAK \\
\hline Motivasi Belajar & 66 & 104.74 & 8.16 & 87 & 121 \\
\hline Hasil Belajar & 66 & 79.23 & 4.62 & 70 & 90 \\
\hline
\end{tabular}

1. Motivasi Belajar

Analisis deskriptif motivasi belajar responden penelitian, diperoleh rerata hitung $=$ 104,74 , standar deviasi $=8,16$, nilai minimum $=87$, dan maksimum $=121$. Jelasnya dapat disajikan pada diagram berikut :

Tabel 8. Distribusi Frekuensi Data Motivasi Belajar

\begin{tabular}{|c|c|c|}
\hline Kelas Interval & Frekuensi Absolut & Frekuensi Relatif(\%) \\
\hline $87-95$ & 12 & 18,18 \\
\hline $96-104$ & 17 & 25.76 \\
\hline $105-113$ & 31 & 46.97 \\
\hline $114-122$ & 6 & 9.09 \\
\hline$\sum$ & 66 & 100 \\
\hline
\end{tabular}

Untuk lebih jelasnya dapat dilihat gambar berikut :

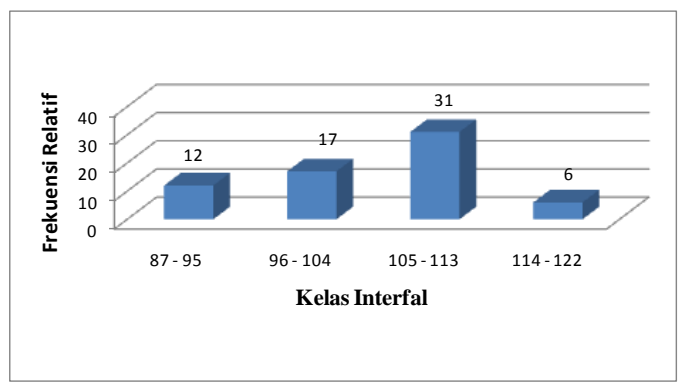

Gambar 2. Grafik Data Motivasi Belajar

2. Hasil Belajar

Analisis deskriptif data hasil belajar, diperoleh rerata hitung $=79,23$, standar deviasi $=4,62$, nilai minimum $=79$, dan maksimum $=90$. Jelasnya dapat disajikan pada diagram berikut :

Tabel 9. Distribusi Frekuensi Data Hasil Belajar

\begin{tabular}{|c|c|c|}
\hline Kelas Interval & Frekuensi Absolut & Frekuensi Relatif (\%) \\
\hline $70-78$ & 23 & 34.84 \\
\hline $79-87$ & 42 & 63.64 \\
\hline $88-96$ & 1 & 1.52 \\
\hline$\Sigma$ & 66 & 100 \\
\hline
\end{tabular}

Untuk lebih jelasnya dapat dilihat gambar berikut :

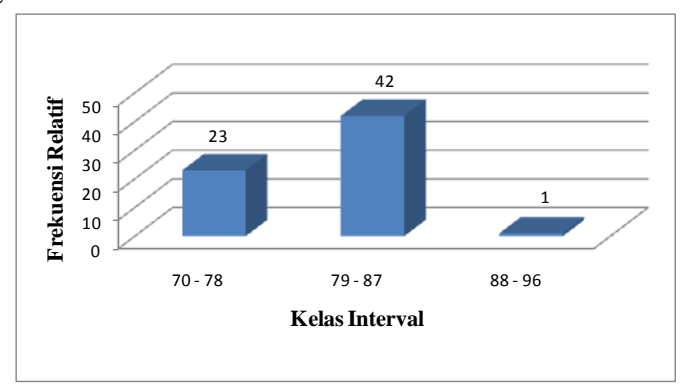

\section{Gambar 3. Grafik Data Hasil Belajar}

Pengujian Persyaratan Analisis

1. Uji Normalitas

Uji normalitas variabel Motivasi Belajar (X) dan Hasil Belajar (Y) menggunakan uji Liliefors, menunjukkan bahwa data tidak berbeda nyata dengan taraf nyata 0.05 , artinya data tersebut berdistribusi normal. Hasil lengkap uji Liliefors test dapat dilihat pada tabel berikut :

Tabel 10. Uji Normalitas Data Penelitian

\begin{tabular}{|c|c|c|c|c|}
\hline Variabel & N & Lo & L tabel & KET \\
\hline Motivasi Belajar & 66 & 0.1069 & 0.109 & Normal \\
\hline Hasil Belajar & 66 & 0.0648 & 0.109 & Normal \\
\hline
\end{tabular}

Ket : Lo $=$ L observasi

Pengolahan dan analisis dilakukan terhadap hubungan motivasi belajar (X) 
dengan hasil belajar masase (Y), menggunakan korelasi product moment pada taraf signifikan 0,005 a. Hasil analisis menunjukkan bahwa motivasi belajar (X) memiliki hubungan yang signifikan terhadap hasil belajar (Y).

Hasil analisis menunjukkan bahwa motivasi belajar mahasiswa (X) memiliki hubungan signifikan dengan hasil belajar, $\mathrm{r}_{\text {hit }}$ $0,533>r_{\text {tab }}$ 0,235. artinya bahwa motivasi belajar sebagai independent variabel memiliki hubungan signifikan dengan dependent variabel yaitu hasil belajar mahasiswa, dengan demikian hipotesis kerja (Ha) yang diajukan dapat diterima.

Setelah itu dilakukan Uji Distribusi t diperoleh $t_{\text {hitung }} 6,98>t_{\text {tabel }} 1,663$ berarti dapat ditarik kesimpulan besar pengaruh motivasi terhadap hasil belajar masase mahasiswa FIK UNP.

\section{Pembahasan}

Berdasarkan data hasil belajar penelitian yang telah diuraikan di atas,hubungan motivasi belajar dengan hasil belajar terhadap pembelajaran masase dasar mahasiswa Fakultas Ilmu Keolahragaan Universsitas Negeri Padang, faktor-faktor tersebut seharusnya saling mendukung agar pelaksanaan pembelajaran masase dasar di FIK UNP dapat terlaksana dengan baik sesuai dengan yang diharapkan.

Dalam proses belajar mengajar tidak terkecuali proses belajar mengajar masase dasardosen memegang peranan penting, karena ini merupakan serangkaian kegiatan dosen dan mahasiswa atas dasar hubungan timbal balik (interaksi), dimana peristiwa ini berlangsung dalam situasi edukatif untuk mencapai tujuan perkuliahan masase dasar.

Dengan mengajak, merangsang dan memberikan kesempatan pada mahasiswa untuk ikut serta mengemukakan pendapat, belajar mengambil keputusan, bekerja dalam kelompok, membuat laporan, berdiskusi dan lain-lainnya lagi, berarti membawa mereka kedalam suasana belajar atau kuliah yang sesungguhnya dan bukan pada suasana diajar atau dikuliahi belaka.

Dalam lapangan inilah antara lain dosen dapat melaksanakan karya yang kreatif. Banyak dosen yang memandang sebagai tantangan dan memperoleh kegembiraan serta kepuasan dalam menjawab mengenai bagaimanakah cara yang baik untuk mencapai tujuan tersebut.

Didalam hal ini, beberapa metode pengajaran, pertama penyajian pengajaran melalui konsep metode analisti adalah segala elemen gerakan dipisahkan dari gerakan keseluruhan. Dengan melatih setiap bagian,

Selanjutnya dosen memperbaiki kesalahan-kesalahan yang dilakukan mahasiswa menerapkannya sesuai petunjuk dari dosen tersebut.Sedangkan konsep metode sintetis adalah dosen menjelaskan dan mendemonstrasikan keseluruhan elemenelemen gerakan yang ada dalam memberikan perkuliahan.

Mahasiswa melatihkan keseluruhan gerakan tersebut secara kasar dan kemudian dosen memperbaiki kesalahn-kesalahan yang dilakukan mahasiswa tersebut.Akhirnya mahasiswa menerapkan perbaikan-perbaikan gerakan sesuai dengan petunjuk dosen yang bersangkutan.

Misalnya memperlihatkan tingkah laku yang tekun dalam mengikuti dan mengerjakan segala tugas-tugas yang dibebankan kepadanya. Dengan termotivasinya dalam belajar-mengajar, bila dilaksanakan secara kontiniu akan menumbuhkan kemauan dan kerja keras pada diri peserta didik.

Sehingga apabila disalurkan secara baik dapat dihubungkan dengan tujuannya untuk berprestasi. Memperhatikan pengaruh yang diakibatkan dengan motivasi instrinsik menimbulkan kesan kiranya faktor ini dapat terus dikembangkan dalam usaha menumbuh dan mengembangkan motif peserta didik sesuai dengan potensi yang dimiliki.

Dengan memperhatikan pendapat di atas maka dapat dijelaskan bahwa motivasi merupakan dorongan dan rangsangan yang terjadi dalam diri individu yang diwujudkan kepada tingkah laku untuk memenuhi kebutuhan yang diinginkan..

Sarana dan prasarana merupakan alat dan tempat terlaksananya suatu proses belajar mengajar dan merupakan salah satu aspek penunjang yang sangat penting di dalam pembelajarn masase dasar.

Berdasarkan hasil penelitian Sarana dan prasarana terhadap pembelajaran masase dasar sangat menunjang dalam upaya peningkatan kemampuan mahasiswa mempelajari masase dasar. Dengan demikian artinya bahwa sarana 
dan prasarana dalam menunjang pembelajaran masase dasar , masih perlu ditingkatkan sehingga pembelajaran masase dasar dapat berjalan dengan lebih baik kedepannya.

Berdasarkan hal tersebut di atas, jelas bahwa tanpa adanya dukungan dari sarana dan prasarana yang memadai baik dari segi kuantitas maupun kualitas, hal ini berpengaruh terhadap kelancaran dalam proses pembelajaran. Sehingga dengan perlengkapan yang tidak mencukupi, maka pembelajaran tidak akan memuaskan. Jadi salah satu usaha untuk meraih hasil yang baik pembelajaran masase dasar saat ini akan ditentukan oleh sarana dan prasarana, baik dari segi jumlahnya maupun mutunya.

\section{Kesimpulan}

Berdasarkan hasil penelitian tentang hubungan motivasi belajar dengan hasil belajar masase dasar mahasiswa FIK UNP maka dapat disimpulkan "Terdapat hubungan yang signifikan antara motivasi belajar (X) dengan hasil belajar mahasiswa (Y)".

Berdasarkan kesimpulan diatas maka diajukan saran sebagai berikut :

1. Kepada mahasiswa agar meningkatkan motivasi belajar supaya memperoleh hasil belajar yang baik.

2. Kepada dosen pengajar khususnya mata kuliah masase dasar di Fakultas Ilmu Keolahragaan Universitas Negeri Padang diharapkan dapat memperhatikan faktorfaktor motivasi dalam perencanaan perkuliahan.

3. Kepada pimpinan Fakultas hendaknya mempersiapkan sarana dan prasarana masase lebih diperbarui sesuai dengan standar Internasional.

4. Kepada Fakultas Ilmu Keolahragaan Dan Jurusan Pendidikan Olahraga dapat menambah pengetahuan dosen di dalam pengembangan ilmu masase.

\section{DAFTAR PUSTAKA}

A Muri Yusuf. 2005. Metodologi Penelitian. (Dasar-Dasar Penyelidikan Ilmiah). Padang: UNP Padang.

Alnedral.1991. Pengaruh Metoda Belajar Dan Minat Mahasiswa Terhadap Prestasi Belajar Bola Volli.(Skripsi).Padang : FPOK IKIP Padang.
Almen.2006. Minat Siswa Putri Terhadap Pembelajaran Penjas Pada Madrasyah Aliyah Negeri Koto Baru Kab.Dharmasraya.(Skripsi). Padang: FIK UNP.

Arikunto, Suharsimi. (1990). Prosedur Penelitian. Jakarta: Rineka Cipta.

Hamalik, Oemar. 2003. Kurikulum dan Pembelajaran. Jakarta: Bumi Aksara.

Hamzah B. Uno.(2012). Teori Motivasi dan pengukurannya analisis di bidang pendidikan.Jakarta : Bumi Aksara

Martinis Yamin.(2011). Paradigm Baru Pembelajaran.Jakarta : Guna Persada

Prayitno. Elida. (1989). Motivasi Belajar. Jakarta: P2LPTK.

Purwanto.(2003). Psikologi Pendidikan.Bandung : PT. Remaja Rosda Karya

Grafindo Persada

Slameto.(2010). Belajar dan faktor yang mempengaruhi. Jakarta: Rineka cipta

Sugiyono. (2006). Metode Penelitian Kuantitatif dan Kualitatif dan $R \& D$. Bandung,Alfabeta.

Sukmadinata.(2003). Landasan Psikologi Proses Pendidikan.Bandung : PT Remaja Rosda Karya

Suryabrata, Sumadi. (1984). Psikologi Pendidikan. Jakarta: Rajawali.

Syahrastani.(1999) Olahraga.Padang : FIK UNP

Syaiful Sagala. (2012). Konsep dan Makna Pembelajaran.Bandung: Alfabeta

Winkel, W.S. (1996). Psikologi Pengajaran. Jakarta: Gramedia.

Hubungan Motivasi Belajar Dengan Hasil..... 18 Edwarsyah ${ }^{1}$, Hilmainur Syampurma ${ }^{2}$ 